\title{
Metastatic seeding in Staphylococcus infection
}

\author{
Navneet Arora @ (1) ${ }^{1}$ Atul Saroch, ${ }^{1}$ Nikita Verma, ${ }^{2}$ Pankaj Gupta ${ }^{2}$
}

IInternal Medicine, PGIMER, Chandigarh, India

${ }^{2}$ Radiodiagnosis, PGIMER,

Chandigarh, India

Correspondence to

Dr Atul Saroch;

atulsaroch@gmail.com

Accepted 27 January 2021

\section{DESCRIPTION}

A 14-year-old male patient presented to the emergency room with fever, loose stools, shortness of breath and swelling over the right popliteal fossa for 5 days. He had no significant past medical history and received all the vaccinations according to the immunisation schedule. He had an oxygen saturation of $96 \%$ on $4 \mathrm{~L} / \mathrm{min}$ of oxygen via nasal cannula. The chest radiograph showed consolidation in the right lung with hydropneumothorax. (figure 1A) The pleural fluid analysis revealed empyema and blood cultures were positive for staphylococcus aureus sensitive to oxacillin, vancomycin and linezolid. Serial transthoracic echocardiography showed normal valve morphology with no vegetations. CT of chest and abdomen revealed right-sided pleural effusion and consolidation in the right lower lobe, and hypodense areas in the spleen signifying splenic infarcts. (figure 1B,C) Ultrasonography of the right popliteal fossa showed a popliteal vein with its lumen distended with hypoechoic content, suggestive of thrombosis along with a small abscess. (figure 2) A diagnosis of Staphylococcus aureus bacteraemia was kept and the patient was started on intravenous oxacillin according to the culture sensitivity. Empyema and the popliteal abscess were drained. The patient improved and was discharged from the hospital.

Staphylococcus aureus is both a commensal organism and also an important opportunistic human pathogen, causing a variety of pathologies such as bacteraemia sepsis, endocarditis, pneumonia, osteomyelitis and skin diseases. Risk factors for Staphylococcus aureus bacteraemia include extreme age, HIV-infected individuals,

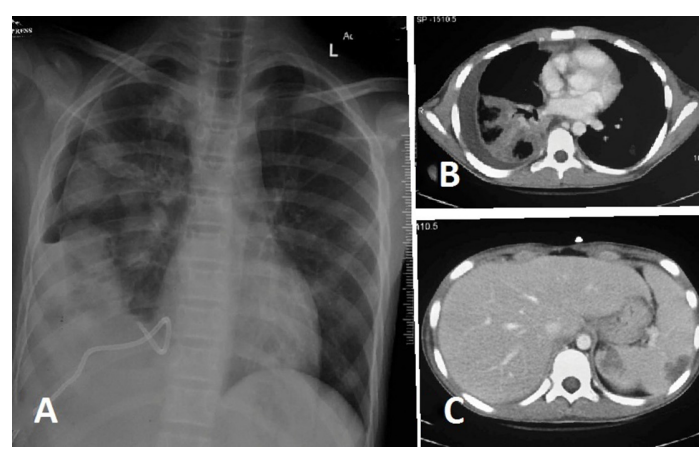

Figure 1 (A) Chest radiograph showing consolidation in the right lung and right hydropneumothorax. The pigtail catheter is seen in-situ. (B) Axial contrastenhanced CT image of thorax showing right-sided pleural effusion and consolidation in the right lower lobe. (C) Axial contrast-enhanced $\mathrm{CT}$ image of the upper abdomen showing peripheral, wedge-shaped non-enhancing areas in spleen suggestive of infarcts.
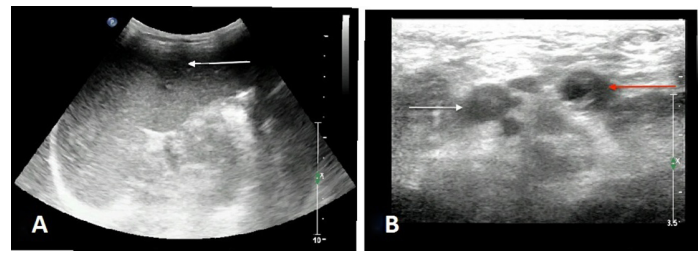

Figure 2 (A) Longitudinal grey-scale ultrasound image of the left hypochondrium showing a peripheral, wedgeshaped hypoechoic area in the spleen (white arrow), suggestive of infarct. (B) Transverse grey-scale ultrasound image of popliteal fossa showing popliteal vein (white arrow), with its lumen distended with hypoechoic content, suggestive of thrombosis. The red arrow shows a small abscess.

intravenous drug users, impaired host immune defences like neutrophil dysfunction, iron overload and diabetes mellitus. ${ }^{1} 2$ The incidence of Staphylococcus aureus bacteraemia in highincome countries is estimated between 8 to 26 per 100000 per year. ${ }^{3}$ Staphylococcus aureus bacteraemia can be classified as complicated or uncomplicated. Complicated infection is one that results in mortality, central nervous system involvement, embolic phenomena, metastatic site infections or recurrences within 12 weeks. Thirty days mortality in case of bacteraemia without focus is $22 \%$ to $48 \% .^{4}$ Staphylococcus aureus bacteraemia

\section{Patient's perspective}

I understand the illness and the complications related to the illness I have. I know with all the efforts of the healthcare workers and the treatment given by them I will surely beat this illness and walk home.

\section{Learning points}

Disseminated staphylococcal infection is reported very rarely nowadays due to improvement in personal hygiene and availability of appropriate and effective antibiotics.

- Infective endocarditis is one of the closest differential diagnoses of disseminated staphylococcal infection.

- Here in this case thorough search leads to the identification of popliteal abscess as a seeding source for disseminated staphylococcal infection, not infective endocarditis. 
is managed by identifying and removing the infected focus, and appropriate antimicrobial therapy with regard to agent, dose and duration.

Contributors NA: preparation, revision of the manuscript and patient management. AS: preparation, revision, supervision of the manuscript and patient management. NV: radiological investigations and picture legends. PG: radiological investigations.

Funding The authors have not declared a specific grant for this research from any funding agency in the public, commercial or not-for-profit sectors.

Competing interests None declared.

Patient consent for publication Parental/guardian consent obtained.

Provenance and peer review Not commissioned; externally peer reviewed.
ORCID iD

Navneet Arora http://orcid.org/0000-0002-4507-2468

\section{REFERENCES}

1 Dayan GH, Mohamed N, Scully IL, et al. Staphylococcus aureus: the current state of disease, pathophysiology and strategies for prevention. Expert Rev Vaccines 2016;15:1373-92

2 David MZ, Daum RS. Community-Associated methicillin-resistant Staphylococcus aureus: epidemiology and clinical consequences of an emerging epidemic. Clin Microbiol Rev 2010;23:616-87.

3 McMullan BJ, Campbell AJ, Blyth CC, et al. Clinical Management of Staphylococcus aureus Bacteremia in Neonates, Children, and Adolescents. Pediatrics 2020;146. doi:10.1542/peds.2020-0134. [Epub ahead of print: 05 Aug 2020].

4 Tong SYC, Davis JS, Eichenberger E, et al. Staphylococcus aureus infections: epidemiology, pathophysiology, clinical manifestations, and management. Clin Microbiol Rev 2015;28:603-61.

Copyright 2021 BMJ Publishing Group. All rights reserved. For permission to reuse any of this content visit

https://www.bmj.com/company/products-services/rights-and-licensing/permissions/

BMJ Case Report Fellows may re-use this article for personal use and teaching without any further permission.

Become a Fellow of BMJ Case Reports today and you can:

- Submit as many cases as you like

- Enjoy fast sympathetic peer review and rapid publication of accepted articles

- Access all the published articles

Re-use any of the published material for personal use and teaching without further permission

\section{Customer Service}

If you have any further queries about your subscription, please contact our customer services team on +44 (0) 2071111105 or via email at support@bmj.com.

Visit casereports.bmj.com for more articles like this and to become a Fellow 